\title{
CONVERSION OF CALCIUM SULFATE DIHYDRATE INTO CALCIUM PHOSPHATES AS A ROUTE FOR CONSERVATION OF GYPSUM STUCCOES AND SULFATED MARBLE
}

\author{
Enrico Sassoni ${ }^{1,}$, , Gabriela Graziani ${ }^{1}$, Elisa Franzoni ${ }^{1}$, George W. Scherer ${ }^{2}$ \\ ${ }^{1}$ Department of Civil, Chemical, Environmental and Materials Engineering (DICAM), \\ University of Bologna, Via Terracini 28, 40131, Bologna, Italy \\ ${ }^{2}$ Department of Civil and Environmental Engineering (CEE), \\ Princeton University, 69 Olden Street, 08542, Princeton (NJ), U.S.A. \\ * corresponding author: enrico.sassoni2@unibo.it
}

\begin{abstract}
To increase the water resistance of gypsum-based stuccoes (i.e., pastes and mortars), the possible conversion of gypsum into less soluble calcium phosphates (CaP), by reaction with an aqueous solution of diammonium hydrogen phosphate (DAP), was investigated. The effect of several reaction parameters (DAP concentration, ethanol addition to the DAP solution, $\mathrm{pH}$ ) on nature and morphology of the new CaP was explored. For the most promising formulation, the ability to improve mechanical properties and reduce solubility in water of treated stuccoes was investigated. The treatment provided better results than ammonium oxalate (an inorganic treatment frequently used for consolidation, protection and de-sulphation of carbonate stones), but the high reaction speed limited the penetration depth and the performance of the DAPtreatment.
\end{abstract}

\section{KEYWORDS}

Hydroxyapatite; Brushite; Gypsum; Marble; Solubility; Consolidation; Protection; Acid rain; Cultural Heritage; Stucco 


\section{1. INTRODUCTION}

2 Pastes and mortars based on gypsum $\left(\mathrm{CaSO}_{4} \cdot 2 \mathrm{H}_{2} \mathrm{O}\right)$, formed from the reaction

3 between the binder bassanite $\left(\mathrm{CaSO}_{4} \cdot 1 / 2 \mathrm{H}_{2} \mathrm{O}\right)$ and water, have been used since

4 ancient times to create plasters, renders and bedding mortars. The so-called stuccoes

5 (i.e. pastes and mortars molded to create decorative elements) have been used to

6 imitate white and colored marbles, when the supply of real stones from distant quarries

7 was too costly [1].

8 Because of the high solubility of gypsum in water $(\sim 2.5 \mathrm{~g} / \mathrm{l})$, decorative elements 9 exposed to rain, rising damp or water vapor condensation may undergo progressive 10 dissolution, leading to surface recession and pulverization [2]. Figure 1 illustrates some 11 examples of gypsum decorations severely weathered because of their exposure to rain 12 and/or rising damp.
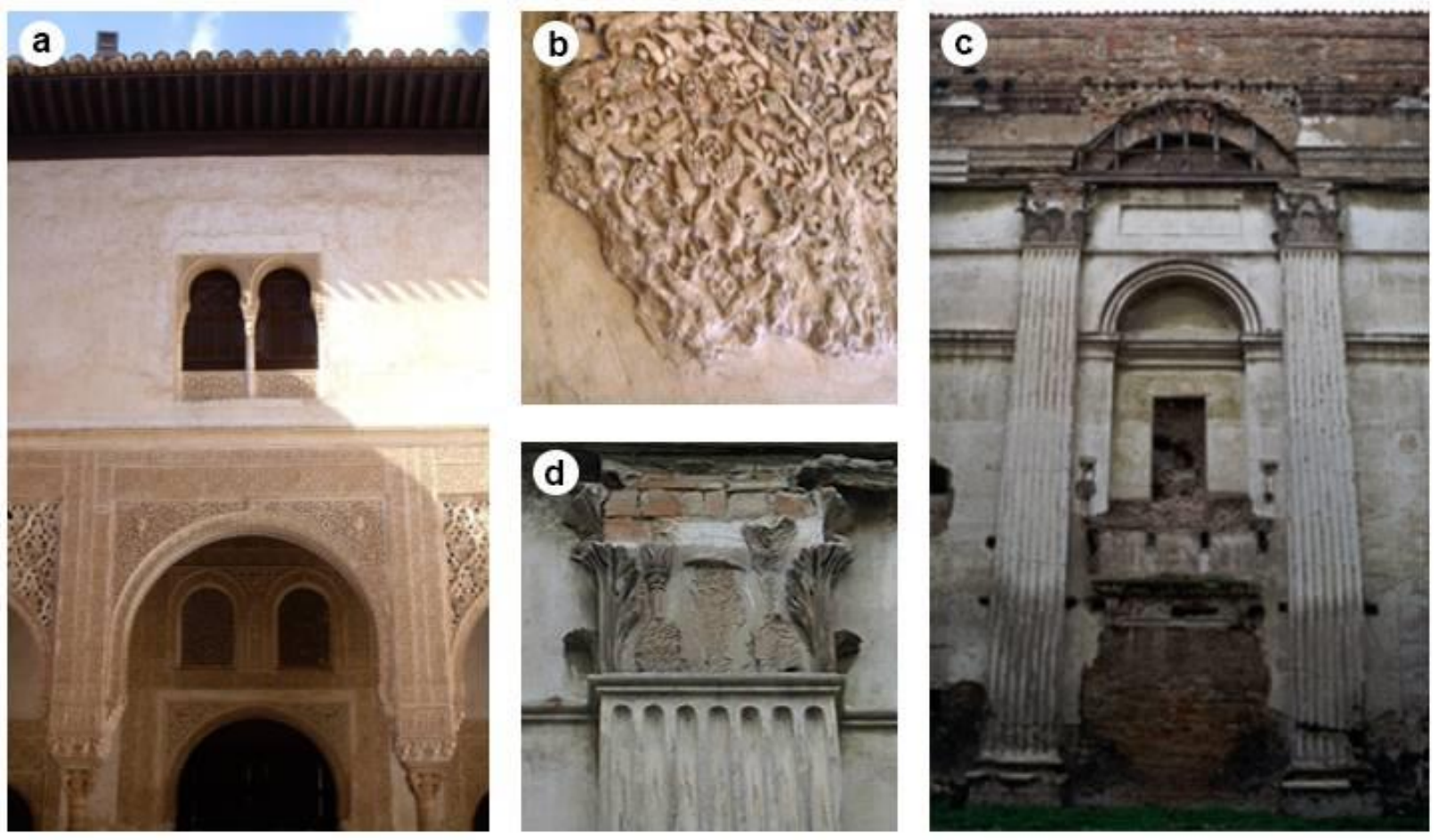

14 Figure 1. Examples of weathered gypsum decorations: $(a, b)$ decorations in the Alhambra Palace in

15 Granada (Spain, XIV century) exposed to rain; (c,d) stuccoes in the church of San Francesco in Fano

16 (Italy, XIX cent.) exposed to rising damp from the ground and rain (because of the collapse of the church 17 roof). 
18 At the time of gypsum stucco creation, it was common practice to add several types of

19 organic additives to the stucco recipes, with the aim of increasing their durability.

20 Sugars, glycerin and citric acid were added to reduce solubility in water [3], while animal

21 blood, egg whites and casein were added to achieve water-repellency [4-6]. Currently,

22 protectives and consolidants are often used. However, commercial treatments (such as

23 ethyl silicate and organic polymers) have exhibited serious limitations when applied to

24 gypsum stuccoes [7]. Ethyl silicate provides little mechanical strengthening, because of

25 the poor bonding between the substrate and the amorphous silica coating, which is

26 affected by diffused cracking; organic polymers exhibit low penetration depth, thus

27 creating a surface layer blocking the pores and negatively altering the water

28 permeability [7]. For these reasons, innovative solutions are needed.

29 A novel route to preserve gypsum-based elements is converting gypsum into less 30 soluble calcium phosphates $(\mathrm{CaP})$, by treatment with an aqueous solution of

31 diammonium hydrogen phosphate (DAP, $\left.\left(\mathrm{NH}_{4}\right)_{2} \mathrm{HPO}_{4}\right)$. Transforming gypsum into a

32 different mineral might raise concerns in the field of cultural heritage conservation,

33 where very strict requirements about authenticity apply [8]. However, because

34 preserving an artifact by using the same type of mineral is not always feasible and/or

35 effective, conservation of architectural heritage by formation of minerals possibly

36 different from the original ones is commonly accepted and performed in practice. For

37 instance, amorphous silica and polymers (formed by silicate and organic consolidants,

38 respectively) are currently used for conservation of gypsum stuccoes in spite of the

39 above-mentioned limitations of these treatments. Therefore, the compatibility

40 requirement is often interpreted as allowing a treatment that does not have negative

41 consequences on the original substrate [9], which is expected to be the case of

42 phosphate treatment aimed at transforming gypsum into calcium phosphates.

43 The reaction between gypsum and DAP solutions has been explored in different fields

44 (e.g., biomaterials [10] and building materials [11,12]) and different chemical reactions

45 have been proposed to describe the gypsum transformation: 
$10 \mathrm{CaSO}_{4} \cdot 2 \mathrm{H}_{2} \mathrm{O}+6\left(\mathrm{NH}_{4}\right)_{2} \mathrm{HPO}_{4} \rightarrow$

$$
\mathrm{Ca}_{10}\left(\mathrm{PO}_{4}\right)_{6}(\mathrm{OH})_{2}+6\left(\mathrm{NH}_{4}\right)_{2} \mathrm{SO}_{4}+4 \mathrm{H}_{2} \mathrm{SO}_{4}+18 \mathrm{H}_{2} \mathrm{O}[10]
$$

$$
\mathrm{Ca}_{10}\left(\mathrm{PO}_{4}\right)_{6}(\mathrm{OH})_{2}+10\left(\mathrm{NH}_{4}\right)_{2} \mathrm{SO}_{4}+\mathrm{H}_{2} \mathrm{O}+4 \mathrm{HPO}_{2}^{-}{ }^{-} \text {(aq) }[12]
$$

$$
\text { or }
$$

$$
\begin{aligned}
& 5 \mathrm{CaSO}_{4} \cdot 2 \mathrm{H}_{2} \mathrm{O}+3\left(\mathrm{NH}_{4}\right)_{2} \mathrm{HPO}_{4}+4 \mathrm{NH}_{3} \rightarrow \\
& \mathrm{Ca}(\mathrm{PO})_{3}(\mathrm{OH})+5\left(\mathrm{NH}_{4}\right)_{2} \mathrm{SO}_{4}+\mathrm{H}_{2} \mathrm{O}[11] ;
\end{aligned}
$$

According to reactions 1-3, hydroxyapatite $\left(\mathrm{HAP}, \mathrm{Ca}_{5}\left(\mathrm{PO}_{4}\right)_{3}(\mathrm{OH})\right)$ should form. HAP is usually written as $\mathrm{Ca}_{10}\left(\mathrm{PO}_{4}\right)_{6}(\mathrm{OH})_{2}$, to denote that the crystal unit cell comprises two formula units. Having a dissolution rate in water about 4 orders of magnitude lower than gypsum and being the most stable calcium phosphate [13-15], HAP is the most desirable phase to form. However, in several studies, formation of HAP starting from gypsum was reported to be associated with diffused cracking [10,11], most probably caused by shrinkage during drying [11]. Cracking is undesired, as it can reduce the performance of the HAP layer and even lead to its partial detachment and separation [12]. Alongside HAP [11,12] or even instead of HAP [16], other CaP phases have been reported to form, such as brushite $\left(\mathrm{CaHPO}_{4} \cdot 2 \mathrm{H}_{2} \mathrm{O}\right.$, predicted by reaction 4$)$ and octacalcium phosphate $\left(\mathrm{Ca}_{8}\left(\mathrm{HPO}_{4}\right)_{2}\left(\mathrm{PO}_{4}\right)_{4} \cdot 5 \mathrm{H}_{2} \mathrm{O}\right)$. A list of $\mathrm{CaP}$ phases and their respective properties is reported in Table 1 ; for comparison, the solubility of gypsum is 2.5-3.1 g/L [17]. These CaP phases have solubility in water higher than HAP, but still much lower than gypsum [15], hence their formation is expected to be beneficial, as

5 long as cracking is prevented. According to reactions 1-3, ammonium sulfate $76\left(\left(\mathrm{NH}_{4}\right)_{2} \mathrm{SO}_{4}\right)$ is also expected to form as a by-product. Being highly soluble in water, 
77 ammonium sulfate is expected to be removed by washing with water, as demonstrated 78 experimentally $[11,12]$.

\begin{tabular}{|c|c|c|c|c|}
\hline Abbreviation & Name & Formula & $\begin{array}{l}\mathrm{Ca} / \mathrm{P} \\
\text { ratio }\end{array}$ & $\begin{array}{l}\text { Solubility at } \\
25^{\circ} \mathrm{C}[\mathrm{g} / \mathrm{L}]\end{array}$ \\
\hline HAP & Hydroxyapatite & $\mathrm{Ca}_{10}\left(\mathrm{PO}_{4}\right)_{6}(\mathrm{OH})_{2}$ & 1.67 & $\sim 0.0003$ \\
\hline $\mathrm{CDHA}$ & Calcium-deficient HAP & $\begin{array}{l}\mathrm{Ca}_{10-x}\left(\mathrm{HPO}_{4}\right)_{x}\left(\mathrm{PO}_{4}\right)_{6-x}(\mathrm{OH})_{2-x} \\
(0<x<1)\end{array}$ & $1.5-1.67$ & $\sim 0.0094$ \\
\hline ACP & Amorphous calcium phosphate & $\begin{array}{l}\mathrm{Ca}_{x} \mathrm{H}_{y}\left(\mathrm{PO}_{4}\right)_{2} \cdot \mathrm{nH}_{2} \mathrm{O} \\
\left(\mathrm{n}=3-4.5,15-20 \% \mathrm{H}_{2} \mathrm{O}\right)\end{array}$ & $1.2-2.2$ & n.a. \\
\hline$\beta-$ TCP & $\begin{array}{l}\beta \text {-Tricalcium phosphate } \\
\text { (or calcium phosphate tribasic) }\end{array}$ & $\beta-\mathrm{Ca}_{3}\left(\mathrm{PO}_{4}\right)_{2}$ & 1.5 & $\sim 0.0005$ \\
\hline OCP & Octacalcium phosphate & $\mathrm{Ca}_{8}\left(\mathrm{HPO}_{4}\right)_{2}\left(\mathrm{PO}_{4}\right)_{4} \cdot 5 \mathrm{H}_{2} \mathrm{O}$ & 1.33 & $\sim 0.0081$ \\
\hline DCPD & $\begin{array}{l}\text { Dicalcium phosphate dihydrate } \\
\text { (or brushite) }\end{array}$ & $\mathrm{CaHPO}_{4} \cdot 2 \mathrm{H}_{2} \mathrm{O}$ & 1.0 & $\sim 0.088$ \\
\hline DCPA & $\begin{array}{l}\text { Dicalcium phosphate } \\
\text { anhydrous (or monetite) }\end{array}$ & $\mathrm{CaHPO}_{4}$ & 1.0 & $\sim 0.0048$ \\
\hline MCPM & $\begin{array}{l}\text { Monocalcium phosphate } \\
\text { monohydrate }\end{array}$ & $\mathrm{Ca}(\mathrm{HPO} 4)_{2} \cdot \mathrm{H}_{2} \mathrm{O}$ & 0.5 & $\sim 18$ \\
\hline MCPA & $\begin{array}{l}\text { Monocalcium phosphate } \\
\text { anhydrous (or calcium } \\
\text { phosphate monobasic) }\end{array}$ & $\mathrm{Ca}\left(\mathrm{HPO}_{4}\right)_{2}$ & 0.5 & $\sim 17$ \\
\hline- & Gypsum & $\mathrm{CaSO}_{4} \cdot 2 \mathrm{H}_{2} \mathrm{O}$ & - & $\sim 2.5$ \\
\hline
\end{tabular}

Table 1. Name, abbreviation, formula, $\mathrm{Ca} / \mathrm{P}$, solubility of different $\mathrm{CaP}$ phases and gypsum [15].

82 In a previous preliminary study, we found that reacting specimens of gypsum pastes

83 with a $1 \mathrm{M}$ DAP solution led to the formation of brushite, as well as ammonium sulfate

84 and koktaite $\left(\left(\mathrm{NH}_{4}\right)_{2} \mathrm{Ca}\left(\mathrm{SO}_{4}\right)_{2} \cdot \mathrm{H}_{2} \mathrm{O}\right)$ as by-products [16]. A possible reason why only

85 brushite was formed, and not HAP (as would be expected based on the chemical

86 reactions reported above), may be the lowering of $\mathrm{pH}$ during the reaction (according to

87 reaction $1, \mathrm{H}_{2} \mathrm{SO}_{4}$ should form). If $\mathrm{pH}$ decreases below 4 , formation of brushite is

88 expected, as this phase is the most stable at $\mathrm{pH}<4[18,19]$. Alongside ammonium

89 sulfate, the formation of koktaite as a by-product is thought to result from the high

90 amount of calcium ions in the solution, originating from the high solubility of gypsum in

91 water [16]. 
93 In light of the above reported studies, the aims of the present paper are the following:

94 1) to study the influence of several reaction parameters (viz., concentration of the DAP 95 solution, addition of ethanol, $\mathrm{pH}$ of the DAP solution) on the nature and the morphology of the new CaP phases, and to optimize the treatment by promoting formation of phases with low solubility and preventing cracking;

2) for the most promising formulation, to test the improvement in mechanical properties and the reduction in solubility of gypsum stuccoes resulting from the formation of the new CaP phases;

3) to compare the performance of the most promising formulation of the phosphate treatment with that of ammonium oxalate. The ammonium oxalate treatment was proposed in the 90s for protection of carbonate stones and wall paintings and for desulfation of sulfated substrates [11,20,21]. This latter action can be achieved by transforming gypsum into less soluble calcium oxalate, according to the reaction:

$$
\mathrm{CaSO}_{4} \cdot 2 \mathrm{H}_{2} \mathrm{O}+\left(\mathrm{NH}_{4}\right)_{2} \mathrm{C}_{2} \mathrm{O}_{4} \rightarrow \mathrm{CaC}_{2} \mathrm{O}_{4} \cdot 2 \mathrm{H}_{2} \mathrm{O}+\left(\mathrm{NH}_{4}\right)_{2} \mathrm{SO}_{4}+\mathrm{H}_{2} \mathrm{O} \text {. }
$$
The consolidating ability of the oxalate treatment on gypsum stuccoes was here investigated because a good mechanical improvement has been reported in the case of sugaring marble [21], even if a poor performance has been found in other studies [15] (so that new routes for improving the treatment based on calcium oxalate are currently being investigated [22]).

112 Moreover, based on the results obtained on gypsum stuccoes, the suitability of using 113 the same formulation of the phosphate treatment also for conservation of sulfated 114 marble was preliminarily investigated. The use of DAP solutions for marble protection 115 [23-26] and consolidation [15,27-29] has been studied in the last few years with very 116 encouraging results. However, the cited studies have been carried out on 117 uncontaminated marble samples, whereas marble in the field is often covered with a 118 layer of gypsum. This gypsum layer is the result of the reaction between marble and 119 sulfur dioxide, which was present in the atmosphere in high concentrations in the past 120 decades, before traffic regulation policies led to the current low values [30], and which is 121 still present in places where such regulations have not been established yet. Some pilot 
122 applications of the DAP-based treatment onto naturally decayed stones (exhibiting 123 gypsum contamination) have shown that the presence of gypsum can significantly alter

124 the composition of the CaP phases formed after treatment [15,31]. Therefore, in the 125 present study, a preliminary evaluation of the treatment effect on sulfated marble was 126 carried out, in terms of morphology and composition of the new CaP phases formed 127 after treatment. It is noteworthy that, in the case of sulfated marble, the possible $\mathrm{pH}$ 128 decrease during the reaction (where, according to reaction $1, \mathrm{H}_{2} \mathrm{SO}_{4}$ may form) is 129 potentially a major issue, because it might cause severe aggression to marble 130 underlying the gypsum layer. Therefore, the variation in $\mathrm{pH}$ during treatment of sulfated 131 marble with the DAP solution was carefully monitored.

\section{MATERIALS AND METHODS}

\section{2.1. Materials}

\subsubsection{Gypsum stuccoes}

136 To simulate ancient stuccoes, specimens of gypsum pastes (with no aggregates) were 137 prepared starting from bassanite (the so-called "scagliola"), supplied by Gessificio Prioli 138 srl, Italy (purity 95\%). Bassanite was mixed with water (water/bassanite weight ratio of $1390.5)$ and prismatic specimens $\left(4 \times 4 \times 16 \mathrm{~cm}^{3}\right)$ were cast. After hardening, the specimens 140 were sawn to obtain cubic ( $1 \mathrm{~cm}$ edge length), cylindrical (2 cm diameter, $4 \mathrm{~cm}$ height) 141 and prismatic samples $\left(1 \times 1 \times 16 \mathrm{~cm}^{3}\right)$.

\section{2.1.2. Sulfated marble}

143 To simulate sulfated marble, cubic specimens (1 $\mathrm{cm}$ edge length) of Carrara marble 144 (BasketweaveMosaics.com, USA) were immersed in an aqueous solution of $\mathrm{H}_{2} \mathrm{SO}_{4}$ 145 (Sigma Aldrich) at $\mathrm{pH} 2$ for 24 hours. In this way, a surface layer of gypsum was formed 146 over the marble substrate. 


\section{2.1.3. Chemicals}

148 Diammonium hydrogen phosphate (DAP, $\left(\mathrm{NH}_{4}\right)_{2} \mathrm{HPO}_{4}$, assay $>99 \%$, Sigma Aldrich),

149 ammonium oxalate $\left(\left(\mathrm{NH}_{4}\right)_{2} \mathrm{C}_{2} \mathrm{O}_{4} \cdot \mathrm{H}_{2} \mathrm{O}\right.$, assay $>99 \%$, Sigma Aldrich), calcium chloride

$150\left(\mathrm{CaCl}_{2} \cdot 2 \mathrm{H}_{2} \mathrm{O}\right.$, assay $>99 \%$, Sigma Aldrich), ammonium hydroxide (ACS Grade), 151 ethanol (Fisher-Scientific) and deionized water were used.

\section{2.2. Treatments}

153 A scheme summarizing the various treatment conditions and the respective specimens 154 is reported in Figure 2.
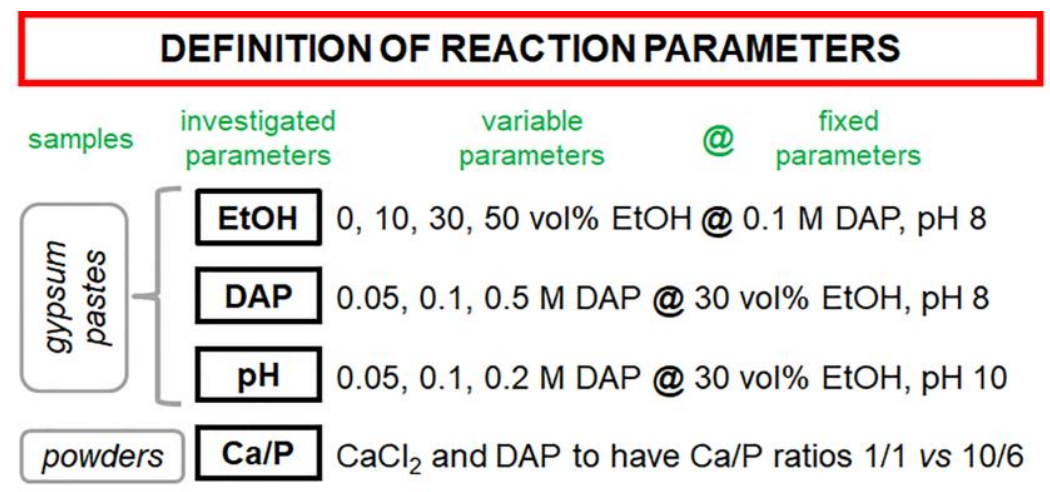

powders $\mathrm{Ca} / \mathrm{P} \mathrm{CaCl}_{2}$ and DAP to have $\mathrm{Ca} / \mathrm{P}$ ratios $1 / 1$ vs $10 / 6$

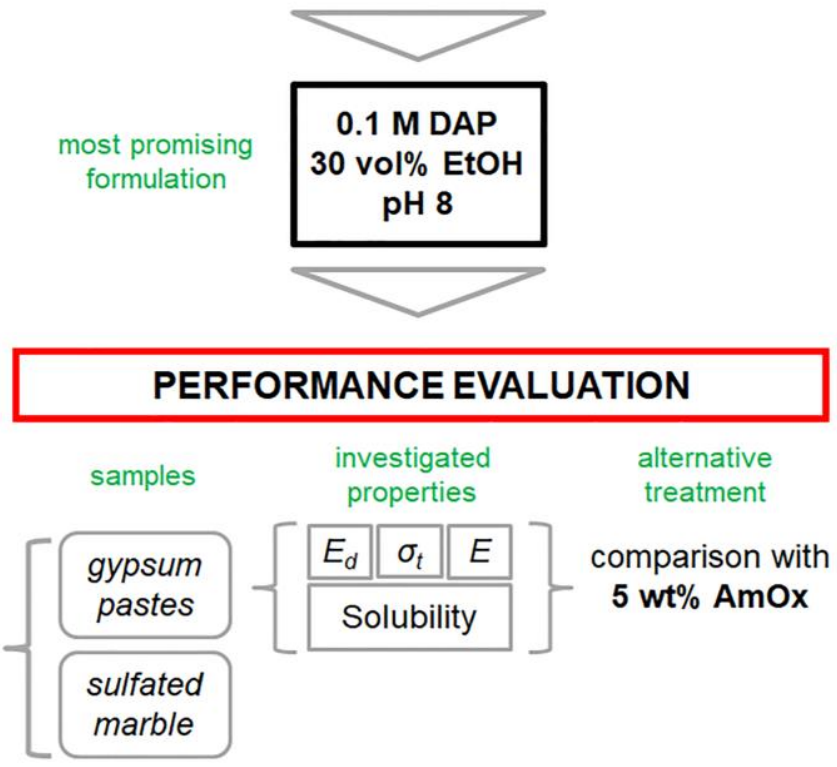

157 Figure 2. Scheme illustrating the various treatment conditions and specimens. 


\subsubsection{Phosphate treatment}

159 Apart from the role of the $\mathrm{Ca} / \mathrm{P}$ ratio (investigated as described in the following), the

160 influence of all the other parameters was tested by immersing specimens of gypsum

161 stuccoes ( $1 \mathrm{~cm}$ cubes) in $200 \mathrm{ml}$ of DAP solution for 24 hours. The variation in $\mathrm{pH}$ of the

162 DAP solution was monitored during the 24-hour reaction. At the end of the treatment, 163 samples were abundantly rinsed with water and then dried at room temperature. The

164 following parameters were considered:

$165>$ ethanol concentration. A previous study had shown that the undesired, soluble 166 phase koktaite was formed when samples of gypsum stuccoes were reacted with a 1 167 M DAP solution [16]. The formation of this phase was ascribed to an excess of 168 calcium ions available in the DAP solution, as a result of the high solubility of 169 gypsum in water. Consequently, a reduction in the solubility of gypsum in the DAP 170 solution (and hence a reduction in the free calcium ions) appears as a promising 171 route to prevent the formation of koktaite. According to the literature, a reduction in 172 gypsum solubility in aqueous solutions can be achieved by adding ethanol to water: 173 a $30 \mathrm{wt} \%$ addition of ethanol to water was found to reduce gypsum solubility by 174 about $30 \%$ [32]. Consequently, ethanol additions of $0,10,30$ and 50 vol\% to a $0.1 \mathrm{M}$ 175 aqueous DAP solution were here investigated. A DAP concentration of $0.1 \mathrm{M}$ was 176 selected (instead of the higher concentrations previously tested in the literature, 177 namely $1 \mathrm{M}$ [16], $3 \mathrm{M} \mathrm{[12]} \mathrm{and} \mathrm{3.8} \mathrm{M}$ [11]) because studies on marble showed that 178 the addition of ethanol to the DAP solution provides a continuous, crack-free and 179 pore-free film, using only millimolar concentrations of DAP. This is possible thanks to 180 the boosting effect that ethanol has on the reactivity of phosphate ions in the solution $181 \quad[25,29]$.

$182>$ DAP concentration. For the ethanol concentration that showed the best results (30 183 vol\%, cf. $\S 3.1$, the effects of higher and lower DAP concentrations were 184 investigated. Samples were reacted in 0.05, 0.1 and 0.5 M DAP solutions, in all 185 cases containing 30 vol\% ethanol.

$186>\mathrm{pH}$ of the DAP solution. Without any $\mathrm{pH}$ modification, a $0.1 \mathrm{M}$ DAP solution has $\mathrm{pH}$ 187 8. However, at higher $\mathrm{pH}$ a higher amount of $\mathrm{PO}_{4^{3-}}$ ions (necessary to form HAP) is 
188 expected to form from DAP dissociation [24,33]. Therefore, the effect of increasing 189 the $\mathrm{pH}$ of the DAP solution from 8 to 10 was investigated. Solutions with increasing 190 DAP concentration ( $0.05,0.1$ and $0.2 \mathrm{M}$, the latter being the maximum concentration 191 not leading to immediate precipitation at $\mathrm{pH}$ 10) were explored, at a constant ethanol 192 concentration of $30 \mathrm{vol} \%$ and $\mathrm{pH}$ 10. The $\mathrm{pH}$ was adjusted using ammonium 193 hydroxide, which was selected among possible bases because it leaves no 194 undesired cations in the solution.

$195>\mathrm{Ca} / \mathrm{P}$ ratio. To study the influence of the starting $\mathrm{Ca} / \mathrm{P}$ ratio on the composition of the 196 new CaP phases, a simplified system was considered. Two aqueous solutions with 197 different $\mathrm{Ca} / \mathrm{P}$ ratios were prepared. DAP was added to a $10 \mathrm{mM}$ aqueous solution of $\mathrm{CaCl}_{2} \cdot 2 \mathrm{H}_{2} \mathrm{O}$ in such an amount to obtain (i) a Ca/P ratio of $10 / 6$ (corresponding to that of HAP) and (ii) a $\mathrm{Ca} / \mathrm{P}$ ratio of $1 / 1$ (corresponding to that of brushite). In both cases, the precipitate was filtered, dried at room temperature and then analyzed by powder X-ray diffraction (XRD), using a Rigaku MiniFlex diffractometer (detector scan range $2 \theta=3-60^{\circ}$, step size $=0.04 \theta$, step time $=0.8 \mathrm{~s}, \mathrm{kV}=40, \mathrm{~mA}=40$ ).

\subsubsection{Oxalate treatment}

204 For comparison's sake, specimens of gypsum stuccoes were also treated by immersion 205 in a 5 wt\% aqueous solution of ammonium oxalate for 24 hours. At the end of the 206 treatment, samples were abundantly rinsed with water and then dried at room 207 temperature.

\section{2.3. Characterization}

209 2.3.1. Nature and morphology of the new CaP phases

210 The mineralogical composition of the new CaP phases formed on the surface of treated

211 samples (1 cm cubes) was determined by grazing incidence diffractometry (GID), using

212 a Bruker D8 Discover X-Ray Diffractometer (incidence radiation $\theta=0.5^{\circ}$, detector scan 213 range $2 \theta=3-37^{\circ}$, step size $=0.02 \theta$, step time $=0.4 \mathrm{~s}, \mathrm{kV}=40, \mathrm{~mA}=40$ ). Thanks to the 214 low penetration depth of the incoming radiation (a few hundreds of nanometers from the 
215 surface), by GID it is possible to determine the composition of the surface layers without

216 interference from the substrate. The same technique was used also for checking the

217 formation of gypsum after the preliminary accelerated sulfation procedure carried out on

218 marble samples (cf. § 2.1.2).

219 The morphology and the possible presence of cracks in the new CaP phases formed

220 after treatment was assessed by observation with an environmental scanning electron

221 microscope (FEI Quanta 200 FEG ESEM) equipped with an energy dispersive x-ray

222 spectroscopy device (Oxford Instruments EDS probe). Before ESEM observation,

223 samples were made conductive by coating with carbon. The same instrument was used

224 also for observing the gypsum layer formed after accelerated sulfation of marble

225 samples (cf. § 2.1.2).

\section{2.3.2. Mechanical properties}

227 The improvement in mechanical properties of the gypsum stuccoes after consolidation

228 was evaluated for (i) the phosphate treatment based on 0.1 M DAP with 30 vol\% 229 ethanol at pH 8 (labeled "DAP") and (ii) for the ammonium oxalate treatment (labeled

230 "AmOx"). The mechanical improvement was evaluated in terms of:

$231>$ dynamic elastic modulus $\left(E_{d}\right)$. $E_{d}$ can be determined non-destructively by measuring 232 the time required by an ultrasonic pulse to cross the sample. Being a non-destructive 233 test, it can be repeated on the same sample before and after consolidation. $E_{d}$ was 234 determined according to the formula $E_{d}=\rho v^{2}$, where $\rho$ is the density and $v$ is the 235 ultrasonic pulse velocity. $v$ was measured across the $4 \mathrm{~cm}$ height of the cylindrical 236 samples by a PUNDIT instrument with $54 \mathrm{kHz}$ transducers, using a rubber couplant 237 to improve the contact. For each condition, 5 samples were tested.

$238>$ static elastic modulus $(E)$. $E$ was tested because, unlike $E_{d}$, it is not affected by the 239 pore-clogging effect that consolidants might have, which could lead to an increase in $240 \quad E_{d}$ without necessarily implying an increase in the actual stiffness. $E$ was determined 241 by three-point beam bending, from the slope of the stress-strain curve obtained by 242 loading the $1 \times 1 \times 16 \mathrm{~cm}^{3}$ samples. Samples were placed on two supports at a 243 distance of $120 \mathrm{~mm}$ and then loaded in the center by a pushrod, activated by a 
244 stepping motor. The load was measured by a $1 \mathrm{~kg}$ load cell, while the deflection was

245 measured by a linear variable displacement transducer (LVDT). E was calculated

246 from the slope of the stress-strain curve, determined by linear regression of five

247 stress-strain coordinates. For each condition, 5 samples were tested.

$248>$ tensile strength $\left(\sigma_{\mathrm{t}}\right) . \sigma_{\mathrm{t}}$ was determined because the tendency of grains to detach

249 from the substrate depends on the material cohesion, which can be evaluated by the

250 splitting test. The same cylindrical samples as for the $E_{d}$ measurement were used.

251 Samples were loaded along two diametric lines until failure, using an Instron testing

252 machine (loading rate $2 \mathrm{~mm} / \mathrm{min}$ ). This method generates tension in a narrow band

253 between the lines of contact, so it is not much affected by treatments that produce

254 only superficial hardening of the cylinder.

\section{2.3.3. Solubility}

256 The reduction in solubility after treatment was determined by a simplified test. After 257 drying to constant weight, untreated and treated cylindrical samples were immersed in $258600 \mathrm{ml}$ of deionized water at initial pH 5 (each sample in a different container), water 259 being kept stirring by a magnetic stirrer. After 24 hours, the samples were extracted 260 from water and dried at room temperature until constant weight. The weight loss after 261 prolonged exposure to water was then determined by comparing the initial and the final 262 weights.

\subsubsection{Penetration depth}

264 The penetration depth of the phosphate and oxalate treatments was assessed by SEM 265 observation of cross sections obtained by chisel from the cylindrical samples used for 266 the splitting tensile test. After coating with aluminum to make them conductive, the 267 samples were observed using a Philips XL20 SEM equipped with an EDAX EDS probe.

\section{RESULTS AND DISCUSSION}

\subsection{Gypsum stuccoes}




\subsubsection{Formation of new CaP phases}

272 The effect of the investigated parameters on the mineralogical composition of the new

$273 \mathrm{CaP}$ phases is reported in Figure 3, while the morphology of the new phases is

274 illustrated in Figure 4, Figure 5 and Figure 6.
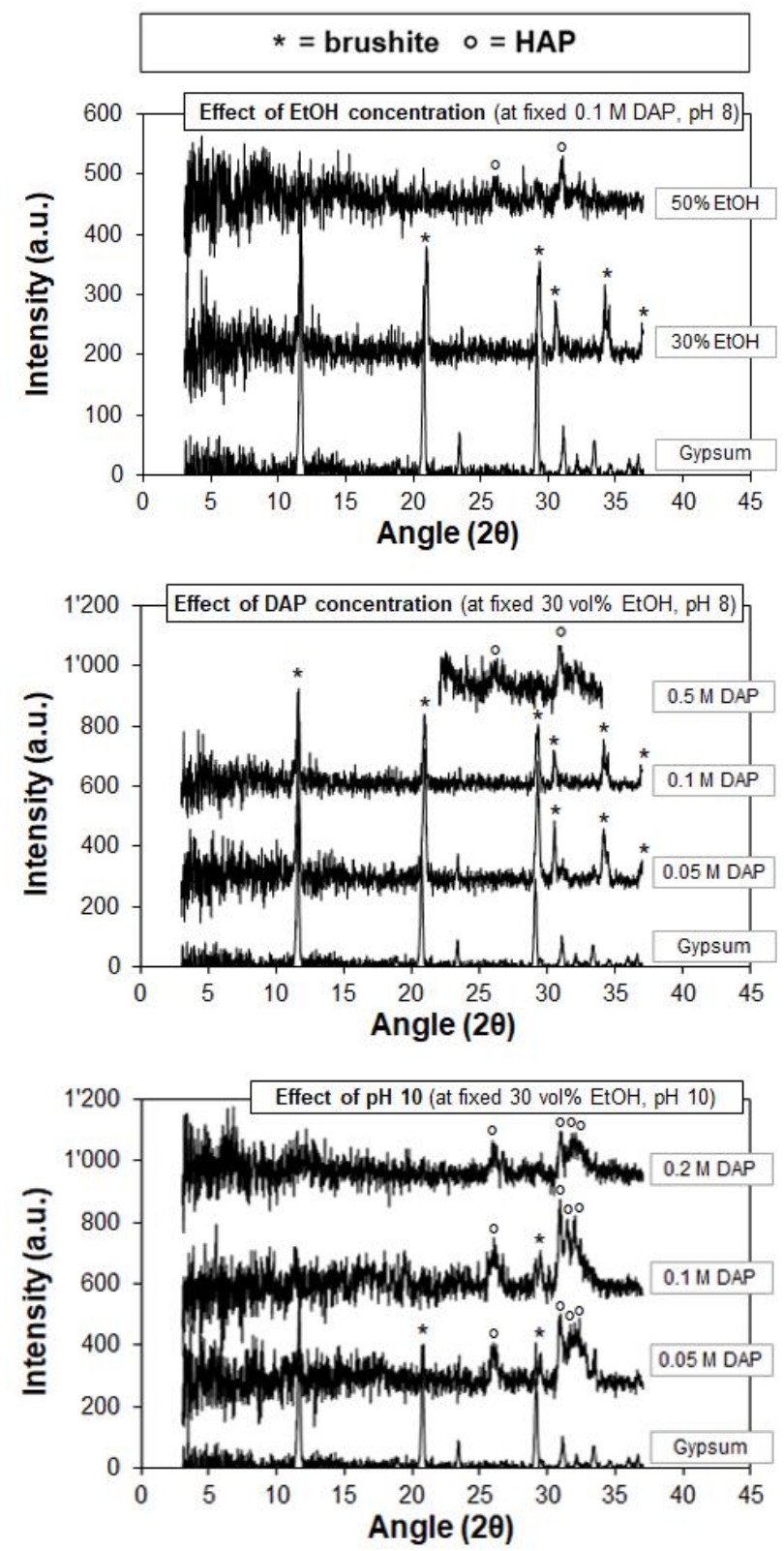

276 Figure 3. Mineralogical composition of the new CaP phases formed by treating gypsum 277 samples with different formulations of the phosphate treatment, to investigate the effect of 278 ethanol concentration (top), DAP concentration (medium) and $\mathrm{pH}$ increase to 10 at various DAP 279 concentrations (bottom). 
Sassoni E., Graziani G., Franzoni E., Scherer G.W., Conversion of calcium sulfate dihydrate into calcium phosphates as a route for conservation of gypsum stuccoes and sulfated marble, Construction and Building Materials 170 (2018) 290-301, DOI: 10.1016/i.conbuildmat.2018.03.075. (c) 2018. This manuscript version is made available under the CCBY-NC-ND 4.0 license http://creativecommons.org/licenses/by-nc-nd/4.0/
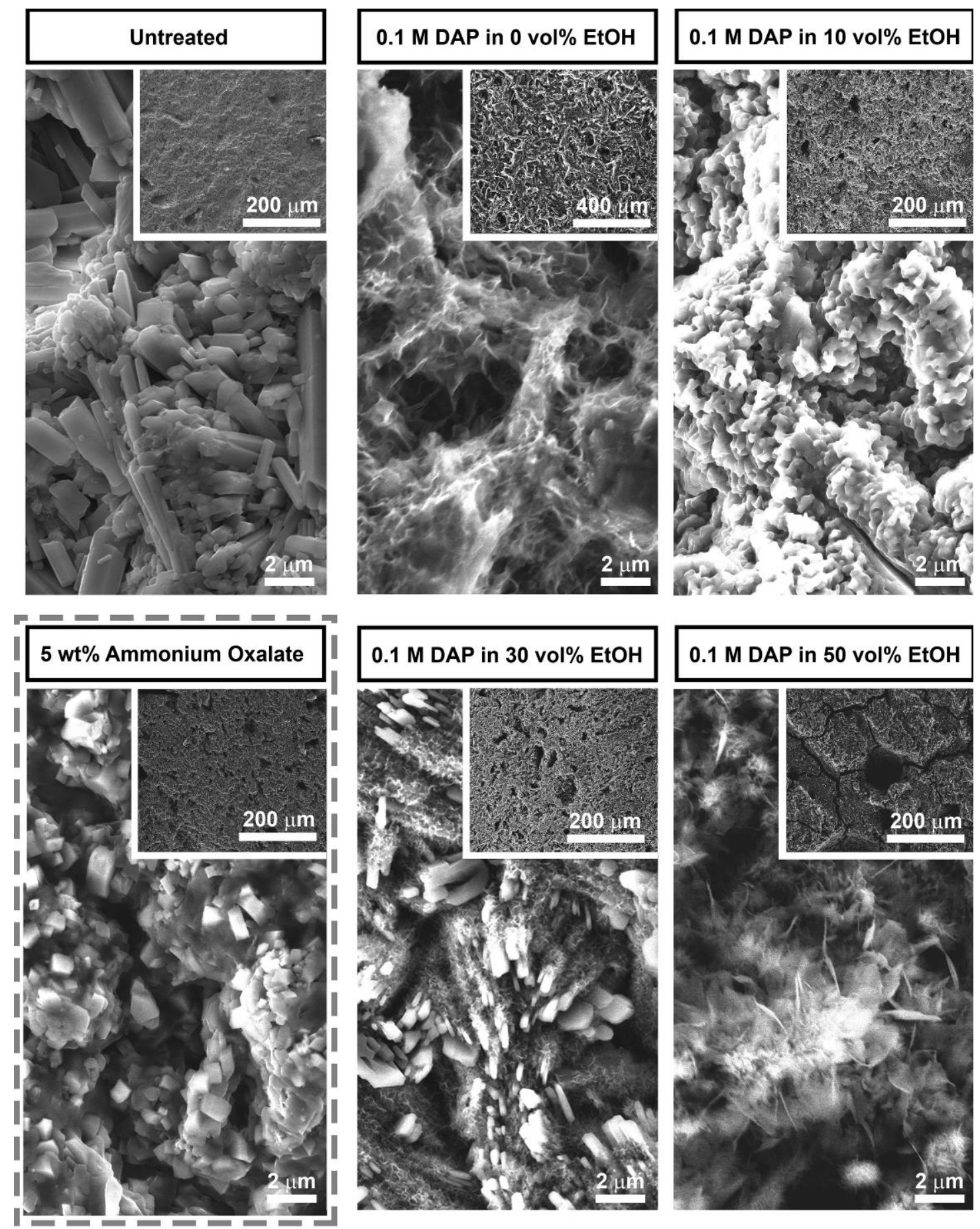

Figure 4. Morphology of the new CaP phases formed by reacting gypsum with different

282 formulations of the phosphate treatment, to investigate the effect of ethanol concentration. For

283 comparison's sake, also the untreated reference and whewellite formed after treatment with

284 ammonium oxalate (dashed box) are reported. 
Sassoni E., Graziani G., Franzoni E., Scherer G.W., Conversion of calcium sulfate dihydrate into calcium phosphates as a route for conservation of gypsum stuccoes and sulfated marble, Construction and Building Materials 170 (2018) 290-301, DOI: 10.1016/i.conbuildmat.2018.03.075. (c) 2018. This manuscript version is made available under the CCBY-NC-ND 4.0 license http://creativecommons.org/licenses/by-nc-nd/4.0/
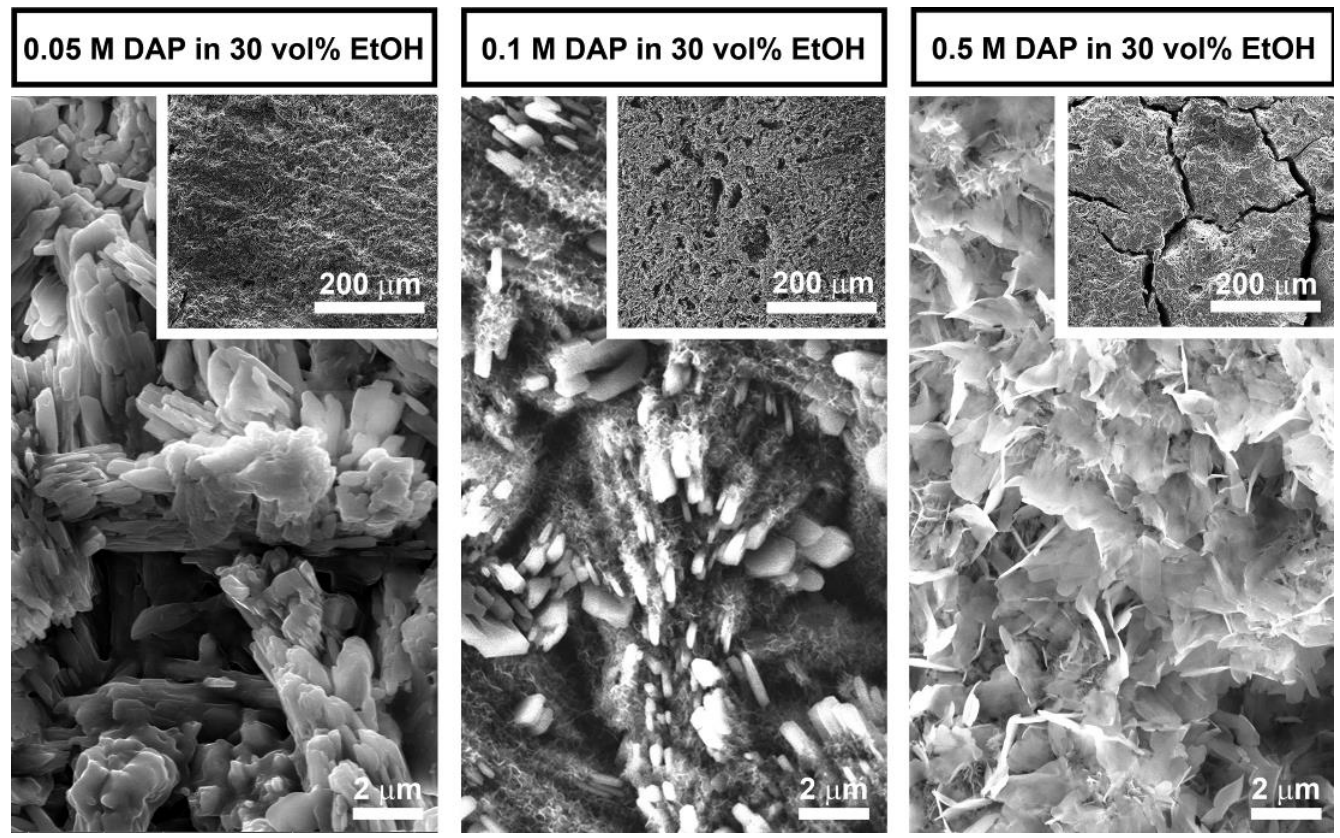

286 Figure 5. Morphology of the new CaP phases formed by reacting gypsum with different

287 formulations of the phosphate treatment, to investigate the effect of DAP concentration.
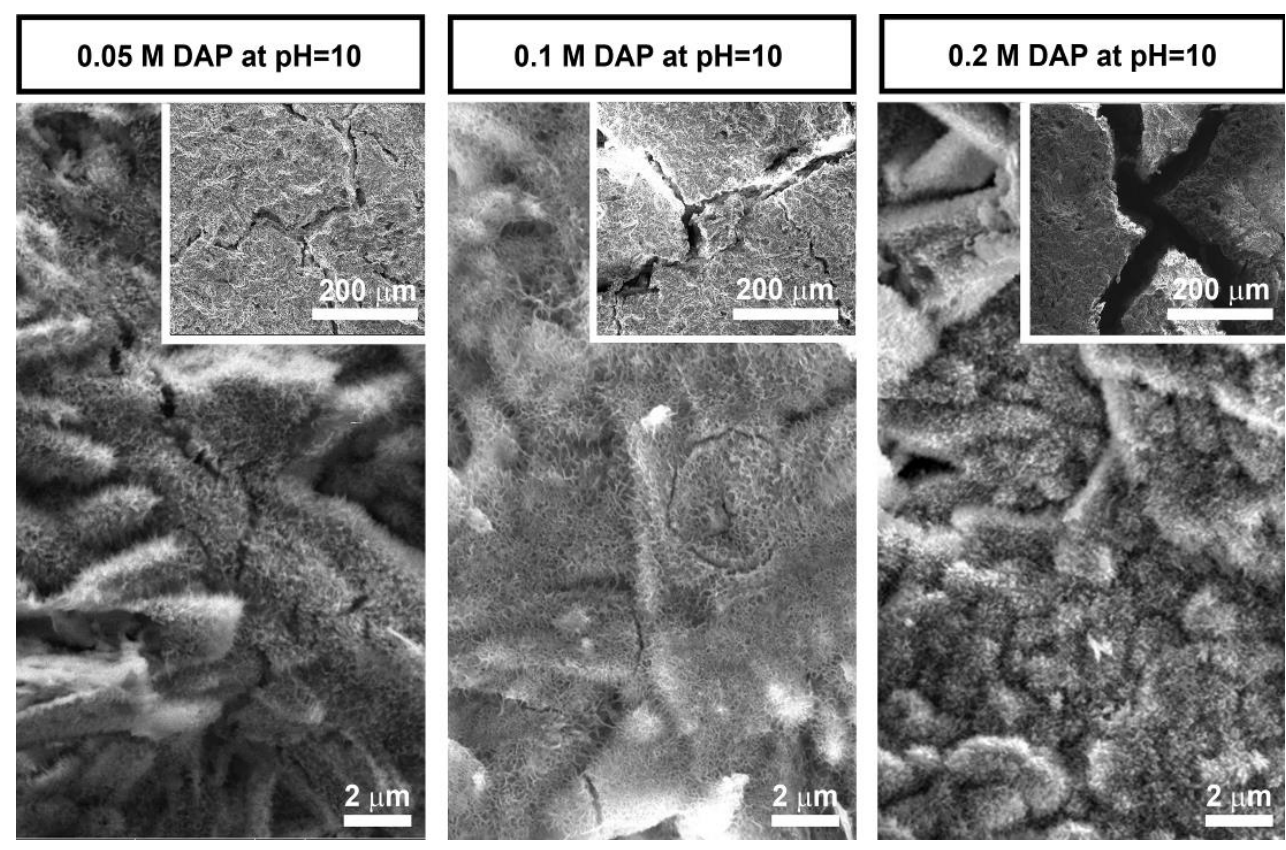

290 Figure 6. Morphology of the new CaP phases formed by reacting gypsum with different

291 formulations of the phosphate treatment, to investigate the effect of increasing $\mathrm{pH}$ to 10 , at 292 various DAP concentrations. 
293 After reaction with a 0.1 M DAP solution containing no or 10 vol\% ethanol addition, 294 some new CaP phases were formed (Figure 4). They could not be identified by GID, 295 likely because of the very small amount produced. The limited formation of CaP phases 296 when such a low DAP concentration was used is consistent with previous results 297 obtained on fresh marble, where no new phases were observed if no ethanol was 298 added to the 0.1 M DAP solution [29]. In the case of gypsum, when the ethanol 299 concentration was increased to 30 and 50 vol\%, abundant new phases were formed, 300 having a clearly different morphology (Figure 4). As reported in Figure 3, the new 301 phases were identified as brushite (30 vol\% ethanol) and HAP (50 vol\% ethanol). In this 302 latter case, the treated sample exhibited diffused cracking (Figure 4), which is 303 undesirable for achieving protection from dissolution in water.

304 When the effect of increasing the DAP concentration was investigated, the modification 305 in phase composition and morphology reported in Figure 3 and Figure 5, respectively, 306 was obtained. Whereas brushite was the main phase formed at 0.05 and $0.1 \mathrm{M} \mathrm{DAP}$, 307 HAP (exhibiting a clearly different morphology, Figure 5) was formed at 0.5 M DAP. 308 However, also in this case, formation of HAP was associated with heavy cracking of the 309 sample surface, while no cracking was observed in samples where brushite formed 310 (Figure 5).

311 Formation of HAP is expected from reactions 1-3, but in some of the investigated 312 conditions brushite was formed instead of HAP. A possible explanation for this might be 313 the lowering of $\mathrm{pH}$ during the reaction as predicted by reaction 1. If $\mathrm{pH}$ decreases below 314 4, then brushite would be the most stable CaP phase and hence its formation would be 315 expected [19]. To verify whether this was the case, in all the experiments the $\mathrm{pH}$ was 316 monitored. The $\mathrm{pH}$ was found to change only slightly during the reaction (from 8.1 to 317 8.0), hence never getting below 4. Therefore, $\mathrm{pH}$ variation was excluded as the possible 318 reason why brushite was formed instead of HAP.

319 Another possible explanation could be that brushite (requiring $\mathrm{HPO}_{4}{ }^{2-}$ ions) is kinetically 320 favored over HAP (requiring $\mathrm{PO}_{4}{ }^{3-}$ ions), as DAP speciation leads to a much higher 321 amount of the former ions with respect to the latter. For instance, in the case of a $0.1 \mathrm{M}$ 
322 DAP solution (with no ethanol addition), calculations performed with Mathematica ${ }^{\circledR}$

323 (following the method described in [24]) predict the following concentrations of

324 phosphate ions: $0.0959 \mathrm{M} \mathrm{HPO}_{4}^{2-}$ ions, $0.0039 \mathrm{M} \mathrm{H}_{2} \mathrm{PO}_{4}^{-}$ions and only $3.3 \times 10^{-5} \mathrm{M}$

$325 \mathrm{PO}_{4}^{3-}$ ions, hence a ratio of $\mathrm{HPO}_{4}{ }^{2-} / \mathrm{PO}_{4}{ }^{3-}$ of about 2900 . The ratio becomes even higher

326 (about 5850) if an amount of $\mathrm{CaCl}_{2}$ sufficient to match gypsum solubility limit $(15.1 \mathrm{mM}$

327 [34]) is also considered in the solution. The hypothesis that brushite is kinetically

328 favored over HAP would also explain the change in phase composition detected for

329 increasing ethanol concentration or increasing DAP concentration. In fact, in either

330 case, the $\mathrm{Ca} / \mathrm{P}$ ratio is decreasing (because fewer $\mathrm{Ca}$ ions are available and more $\mathrm{P}$

331 ions are available, respectively). Because HAP has a higher $\mathrm{Ca} / \mathrm{P}$ ratio than brushite

332 (1.67 vs 1, respectively), formation of HAP would be expected to be favored at higher

333 Ca concentrations (i.e., lower ethanol concentrations) or at lower DAP concentrations.

334 To verify whether formation of brushite occurs because the kinetics predominates over

335 the effect of the $\mathrm{Ca} / \mathrm{P}$ ratio, solutions were prepared with different $\mathrm{Ca} / \mathrm{P}$ ratios, namely

$33610 / 6$ (corresponding to that of HAP) and 1/1 (corresponding to that of brushite) (cf. $\S$

337 2.2.1). As illustrated in Figure 7, in both cases brushite was the main phase that formed,

338 with only minor amounts of HAP. This suggests that, independently of the starting $\mathrm{Ca} / \mathrm{P}$

339 ratio, formation of more soluble brushite is favored over less soluble HAP, likely

340 because $\mathrm{HPO}_{4}{ }^{2-}$ ions needed to form brushite are more easily available than $\mathrm{PO}_{4}{ }^{3-}$ ions

341 needed to form HAP. Accordingly, in a recent paper [12] it was proposed that formation

342 of CaP phases follows the Ostwald's rule, i.e. the phase with the fastest precipitation

343 rate is preferentially formed, even if it is not the most stable one [12].
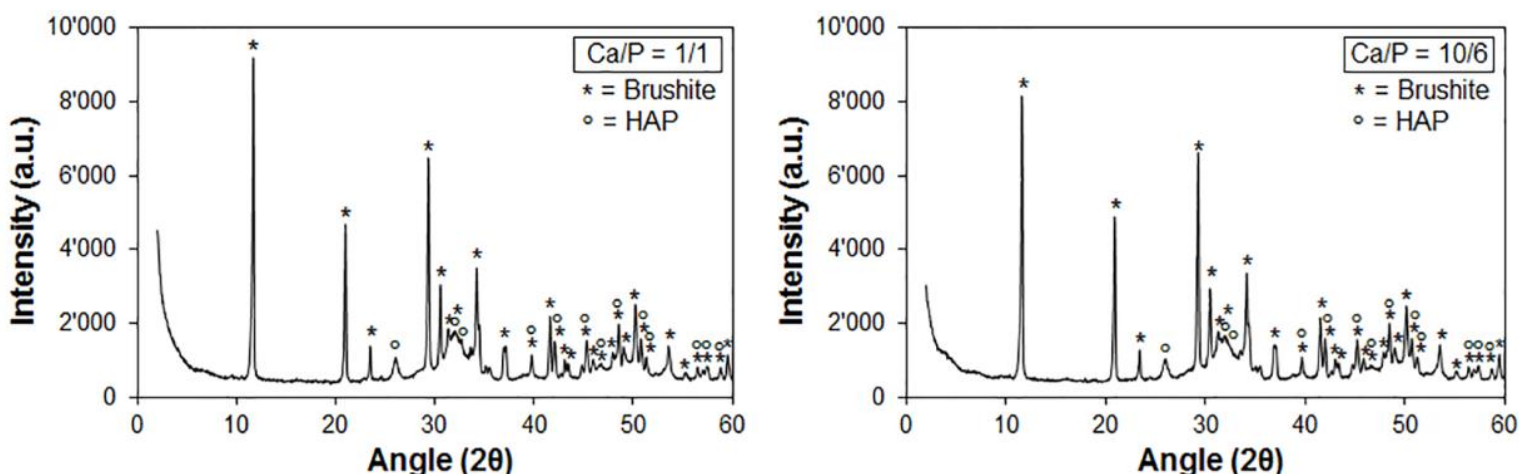

344

345

346

Figure 7. Composition of the new CaP phases precipitated from solutions with $\mathrm{Ca} / \mathrm{P}$ ratio of $1 / 1$ (left) and Ca/P ratio of 10/6 (right). 
347 To promote formation of HAP, we increased the $\mathrm{pH}$ of the starting DAP solution from 8 348 to 10, because more $\mathrm{PO}_{4}{ }^{3-}$ ions (required to form HAP) are available at higher $\mathrm{pH}$ [33].

349 As expected, a significant change in phase composition was achieved by increasing the

$350 \mathrm{pH}$ (Figure 3). At low DAP concentrations (0.05 and $0.1 \mathrm{M})$, brushite was still present, 351 but also HAP was formed. At higher DAP concentration $(0.2 \mathrm{M}$, the highest 352 concentration not leading to direct precipitation at $\mathrm{pH} 10$ ), only HAP was detected. 353 However, in all cases the new CaP phases exhibited diffused cracking (Figure 6), which 354 presumably occurred during drying because the porous films exceeded the critical 355 thickness for cracking (below the critical thickness, cracking is thermodynamically 356 inhibited [35]). In addition to altering the aesthetic appearance of the treated stuccoes 357 (as they are visible even by naked eye), cracks are expected to be detrimental to 358 protection from dissolution in water. Therefore, formulations at $\mathrm{pH} 10$, leading to 359 diffused cracking, were regarded as not promising for providing satisfactory protection.

360 It is noteworthy that in no case was formation of undesired koktaite [16] detected, which 361 was the aim of adding ethanol to the DAP solution (because ethanol reduces the 362 solubility of gypsum in water [32] and hence the amount of free calcium ions in the DAP 363 solution). Moreover, neither was formation of ammonium sulfate detected by GID, which 364 is the positive result of abundantly washing samples with deionized water at the end of 365 the 24 hour reaction. However, this washing procedure was sufficient to entirely remove 366 ammonium sulfate in the samples used for GID (1 cm cubes), but not in bigger samples 367 used for mechanical tests (e.g. cylinders with $2 \mathrm{~cm}$ diameter and $4 \mathrm{~cm}$ height). After 368 treatment, washing and drying, the latter samples exhibited some color change towards 369 grey, owing to formation of ammonium sulfate, detected also by GID. However, by 370 further saturating the samples with deionized water by capillary rise and then 371 submerging the samples, ammonium sulphate was almost completely removed, as 372 indicated by GID and by the color change back to the initial one. Accordingly, no traces 373 of nitrogen were detected by SEM/EDS on cross sections obtained from the cylindrical 374 samples used for the tensile strength test.

375 In light of these results, the formulation of the phosphate treatment based on a $0.1 \mathrm{M}$ 376 DAP solution also containing 30 vol\% ethanol at $\mathrm{pH} 8$ was considered as the most 
377 promising one, as it leads to formation of brushite (significantly less soluble than 378 gypsum, although more soluble than HAP), without cracking. In terms of long term

379 stability, brushite (as well as other metastable CaP phases) are expected to undergo 380 dissolution and reprecipitation processes, finally leading to formation of the most stable 381 CaP phase, i.e. HAP. In the case of a CaP layer formed by reacting gypsum with DAP 382 solutions, progressive densification of the layer with time, thanks to formation of 383 additional CaP phases, was found experimentally [12]. On the contrary, dehydration of 384 brushite to monetite $\left(\mathrm{CaHPO}_{4}\right.$, having much higher water solubility than brushite, Table 385 1) was not found to occur in practical conditions [11]. Therefore, the long term stability 386 of the so-formed brushite is expected to be satisfactory.

387 The consolidating and protecting ability of the above-reported formulation (labeled 388 "DAP") was hence investigated and compared to that of commercial ammonium oxalate 389 (labeled "AmOx").

\subsubsection{Mechanical consolidation}

391 The variations in mechanical properties after application of the phosphate and oxalate 392 treatments are reported in Table 2.

\begin{tabular}{llllll}
\hline & Untreated & DAP & Variation & AmOx & Variation \\
\hline$E_{d}(\mathrm{GPa})$ & $9.9( \pm 0.4)$ & $10.3( \pm 0.1)$ & $+3 \%$ & $11.1( \pm 0.6)$ & $+12 \%$ \\
$E(\mathrm{GPa})$ & $4.0( \pm 0.5)$ & $4.2( \pm 0.2)$ & $+5 \%$ & $4.0( \pm 0.2)$ & $0 \%$ \\
$\sigma_{\mathrm{t}}(\mathrm{MPa})$ & $3.4( \pm 0.7)$ & $3.8( \pm 0.2)$ & $+13 \%$ & $3.3( \pm 0.6)$ & $-3 \%$ \\
$\Delta w(\%)$ & 9.5 & 7.9 & $-17 \%$ & 9.5 & $0 \%$ \\
\hline
\end{tabular}

394 Table 2. Mechanical properties and weight loss after immersion in water of untreated and 395 treated samples ( $E_{d}=$ dynamic elastic modulus; $E=$ static modulus; $\sigma_{\mathrm{t}}=$ tensile strength; $\Delta w=$ 396 weight loss). Values of mechanical properties are averages for 5 samples (standard deviations 397 in brackets). 
399 The DAP treatment caused modest increases in dynamic elastic modulus $E_{d}$ and static 400 modulus $E(+3 \%$ and $+5 \%$, respectively) and a slightly higher increase in tensile 401 strength $(+13 \%)$. This limited mechanical improvement seems to derive from the low 402 depth of formation of new CaP phases, as assessed by SEM/EDS analysis of cross 403 sections. As illustrated in Figure 8 and Figure 9, the formation of new CaP phases and 404 the consequent presence of phosphorus are mainly concentrated in the first 50-100 $\mu \mathrm{m}$ 405 from the surface. Traces of new CaP phases were observed at a depth of $500 \mu \mathrm{m}$ from 406 the surface, while no new phases were detected at $1 \mathrm{~mm}$ (Figure 9). This reduced 407 penetration depth, in spite of the ability of the DAP solution to penetrate deeply into 408 porous substrates (up to $25 \mathrm{~mm}$ in porous limestone [36-38]), is thought to be a 409 consequence of the fast reaction between the DAP solution and gypsum. 410 Notwithstanding the addition of ethanol to the DAP solution to reduce gypsum solubility, 411 the presence of a large amount of calcium ions available for reaction is responsible for 412 the consumption of phosphate ions in the DAP solution, so that new CaP phases form 413 mostly near the surface. Possible strategies for reducing the reaction speed and hence 414 favor formation of the new CaP phases also in depth are currently under investigation.
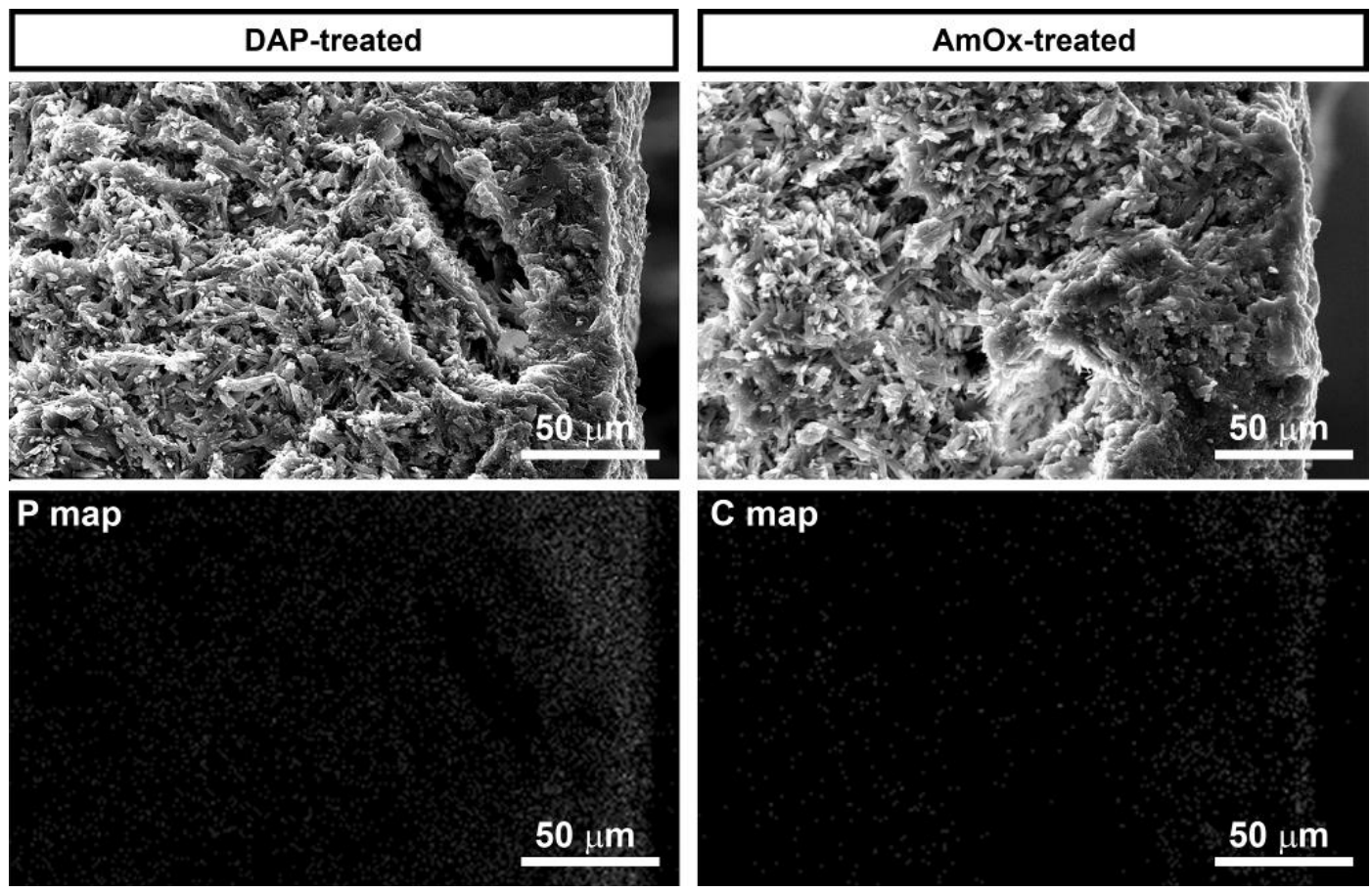

416 Figure 8. Morphology and elemental maps of cross sections of samples treated by DAP (left) 417 and AmOx (right). 

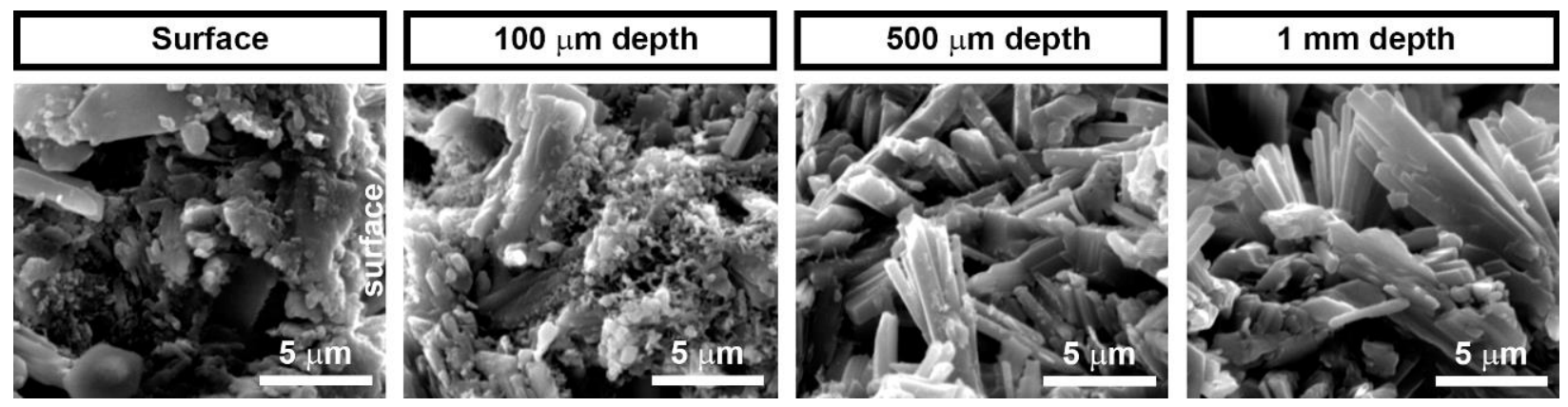

Figure 9. New CaP phases at increasing depth from the surface. Whereas abundant new phases are present near the surface and can still be clearly observed at $100 \mu \mathrm{m}$ depth, only minor traces of new CaP phases are visible at $500 \mu \mathrm{m}$ depth (small flakes formed on the surface of the big gypsum crystals) and no trace is found at $1 \mathrm{~mm}$ depth.

In the case of the AmOx treatment, gypsum was transformed into whewellite $\left(\mathrm{CaC}_{2} \mathrm{O}_{4} \cdot \mathrm{H}_{2} \mathrm{O}\right)$, as indicated by GID and illustrated in Figure 4 (dashed box). In this case, even if a higher increase in $E_{d}$ was registered (+12\%), no significant increase in either the static modulus or the tensile strength was found (Table 2). The lack of any substantial consolidating action is thought to be a consequence of the reduced depth of formation of whewellite, which in turns derives from the kinetics of reaction between the ammonium oxalate solution and the substrate. As recently pointed out in a study on carbonate stones, ammonium oxalate tends to react with calcite more quickly than DAP, which leads to a lower penetration depth of the former treatment compared to the latter [39]. Accordingly, in the case of gypsum (even more soluble than calcite), in the present study a much lower depth of formation of calcium oxalate was found by SEM/EDS, compared to calcium phosphates (Figure 8). The presence of $C$ (assumed as indicative of formation of whewellite) was detected only at a few tens of microns from the surface. This finding is in agreement with previous results reported in the literature on treatment of gypsum with ammonium oxalate and ammonium phosphate solutions [11]. In the cited study, a strong gradient in the formation of calcium oxalate was reported (the highest amount being concentrated near the surface), whereas a more homogenous formation of $\mathrm{CaP}$ phases (present also in depth) was found [11]. The apparent increase in $E_{d}$ registered in the AmOx-treated samples is thought to derive from formation of 
443 ammonium sulfate inside the pores of the samples. In the case of the AmOx treatment, 444 traces of ammonium sulfate were detected by GID even in the $1 \mathrm{~cm}$ cubes, although 445 washed at the end of the treatment. In the cylindrical samples used for $E_{d}$ 446 measurements, while saturation and submersion in water were sufficient to remove 447 basically all the ammonium sulfate from the DAP-treated samples, in the case of the 448 AmOx-treated ones, a considerable amount of ammonium sulfate still remained, as 449 suggested by the color change and confirmed by GID. The difference between the DAP450 and the AmOx-treatments in the amount of ammonium sulfate formed inside the pores 451 and remaining after washing derives from the fact that $\mathrm{NH}_{4}+$ ions were more abundant in 452 the AmOx solution (about $0.4 \mathrm{M}$ ) than in the DAP solution (0.1 M).

453 Comparing the performance of the two treatments, the DAP solution was able to 454 penetrate more in depth and provide greater mechanical improvement than the AmOx 455 treatment, but neither is very effective. Compared to ammonium oxalate, the DAP 456 treatment has the advantage of leading to formation of a smaller amount of ammonium 457 sulfate, that can be more easily removed. For the same reason, even if slightly greater 458 mechanical improvements were found in a previous study where a 1 M DAP solution 459 was used ( $\Delta E_{d}=+5 \%$ and $\Delta \sigma_{t}=+16 \%$ [16]), still the formulation adopted in this study 460 seems preferable, considering that the small mechanical advantage had been obtained 461 at the cost of a much higher DAP concentration (10 times as much) and formation of 462 much more ammonium sulfate (and koktaite) inside the sample [16].

\subsubsection{Protection from dissolution in water}

464 The results of the simplified dissolution tests are reported in Table 2.

465 In the case of the DAP treatment, thanks to gypsum conversion to brushite, a $17 \%$ 466 reduction in weight loss after prolonged exposure to water was registered. The reason 467 why the reduction was not higher (in spite of brushite being about 27 times less soluble 468 than gypsum [15]) is thought to be the porous nature of the brushite layer and of the 469 gypsum substrate, combined with the reduced depth of gypsum conversion to brushite. 470 In fact, porosity allows water to penetrate in depth and reach the inner part of the 471 sample, not completely covered by the newly formed brushite. 
472 In the case of the AmOx treatment, no reduction in weight loss was registered,

473 compared to the untreated reference. This is a consequence of the fact that whewellite

474 formed only in the most superficial part of the sample, because of the high speed of the

475 reaction [11]. Combined with the porous nature of the sample, this prevented an

476 effective protecting action from being achieved.

\section{$477 \quad$ 3.2. Sulfated marble}

478 After immersion in $\mathrm{H}_{2} \mathrm{SO}_{4}$ at $\mathrm{pH} 2$ for 24 hours, gypsum was formed on the marble 479 surface, as confirmed by GID. The newly formed gypsum exhibited a needle-like 480 morphology, as illustrated in Figure 10.
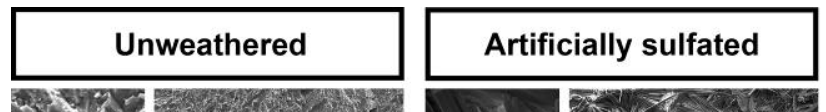

Artificially sulfated, then $0.1 \mathrm{M}$ DAP in $30 \mathrm{vol} \% \mathrm{EtOH}$

483 Figure 10. Morphology of fresh marble (left), artificially sulfated marble (middle) and artificially

484 sulfated marble treated with DAP (right).

486 During reaction with the formulation that gave the best results on gypsum stuccoes 487 (namely, a $0.1 \mathrm{M}$ DAP solution in $30 \mathrm{vol} \%$ ethanol), the $\mathrm{pH}$ of the solution was found to 488 change only slightly, from 8.1 to 8.0. Consequently, no risk of marble corrosion owing to 489 the possible formation of $\mathrm{H}_{2} \mathrm{SO}_{4}$ during reaction of the gypsum layer with the DAP 490 solution (cf. reaction 1 in $\S 1$ ) was present. 
491 After treatment, new CaP phases were formed, as illustrated in Figure 10. These

492 phases exhibit a morphology more similar to that of HAP (Figure 7) than to brushite

493 (Figure 4), but no conclusive phase identification was achieved by GID. This is probably

494 to be ascribed to the reduced thickness of the new CaP phases, as suggested by the

495 fact that these phases closely follow the morphology of the needle-like gypsum crystals

496 originally covering the marble surface. Whatever the nature of the new CaP phases,

497 their solubility is in any case lower than that of gypsum, hence a benefit in terms of

498 resistance to dissolution is expected.

499 However, some micro-cracks were visible in the CaP layer (Figure 10, right), while no

500 similar cracks were observed in the gypsum layer before treatment with the DAP

501 solution. Because the formation of micro-cracks in the CaP layer may negatively affect

502 its durability, further investigation seems opportune to optimize the treatment outcome

503 in the case of sulfated marble, where the morphology of the starting gypsum crystals

504 may affect the phosphate treatment outcome.

505 It is noteworthy that, in the case of marble covered with gypsum layers embedding dust 506 and particulate matter (the so-called "black crusts"), transformation of gypsum into 507 calcium phosphates would encapsulate the dirt in a layer with reduced solubility, which 508 might be counterproductive. Therefore, whenever possible, the dark matter should be 509 removed by cleaning before application of the DAP-based treatment. Nonetheless, in

510 the case of marble covered by black crusts, below which the marble surface is sugaring 511 (so that cleaning the black crust might threaten the conservation of the underlying 512 marble), preliminary tests we have carried out indicate that the DAP treatment, applied 513 over the gypsum crust, is able to pre-consolidate the marble surface, which becomes 514 able to stand the cleaning operations, while the consolidated crust can still be 515 successfully removed by cleaning.

\section{CONCLUSIONS}

517 In the present study, the composition and the morphology of new calcium phosphate 518 phases formed by reacting gypsum pastes with different solutions of diammonium 
519 hydrogen phosphate was investigated and the consolidating and protecting ability of the

520 most promising formulation were evaluated. The following conclusions can be derived:

521 1) Formation of phases with low solubility (e.g., HAP) can be obtained by increasing 522 the ethanol concentration (added to reduce gypsum solubility and hence the amount of calcium ions in the solution), by increasing the DAP concentration or by increasing the $\mathrm{pH}$. However, HAP formation was found to be associated with diffused and visible cracking, likely because of excessive growth of the new phase. On the contrary, when more soluble brushite was formed, no cracking was observed.

2) Formation of brushite was found to be favored over formation of HAP, likely because brushite requires $\mathrm{HPO}_{4}{ }^{2-}$ ions (by far the most abundant species originated from DAP dissociation) while HAP requires $\mathrm{PO}_{4}{ }^{3-}$ ions (which are present only in very minor amounts). This explains why brushite is preferentially formed, even in a $\mathrm{pH}$ range and for a starting $\mathrm{Ca} / \mathrm{P}$ ratio that should favor HAP.

3) Samples of gypsum stuccoes treated for 24 hours with a 0.1 M DAP solution containing 30 vol\% ethanol at $\mathrm{pH} 8$ exhibited formation of uncracked brushite. As brushite is less soluble than gypsum (although more soluble than HAP), such treatment caused a $17 \%$ decrease in weight loss of the gypsum stuccoes after prolonged exposure to water and a $13 \%$ increase in their tensile strength. However, the improvement induced by the phosphate treatment was not as high as hoped because of the reduced depth of formation of brushite, mostly concentrated in the first 50-100 $\mu \mathrm{m}$ from the surface and present only in traces at a depth of $500 \mu \mathrm{m}$. The phosphate treatment provided better results than the ammonium oxalate treatment, originally proposed for desulfation of calcareous substrates and here investigated for consolidation and protection of gypsum stuccoes. The performance of the oxalate treatment is mainly limited by the high speed of reaction between the oxalate solution and gypsum, so that the depth of formation of calcium oxalate is only a few tens of microns from the surface. Possible routes to reduce the speed of reaction between the phosphate solution and gypsum are currently under investigation. In the case of the oxalate treatment, use of a lower concentration of 
548 ammonium oxalate and/or addition of alcohol might improve the performance, but 549 those variations were not explored in the present study.

4) With the aim of treating sulfated marble so as to transform gypsum into less soluble calcium phosphate phases, the same formulation of the phosphate treatment reported above was tested also on artificially sulfated samples of Carrara marble. New calcium phosphate phases with the flower-like morphology typical of HAP were observed, but they could not be identified by GID. Because some cracks were observed in the new calcium phosphate layer, some further optimization of the treatment seems necessary for application to sulfated marble, where the morphology of the gypsum crystals may also play a role.

\section{ACKNOWLEDGMENTS}

559 This project has received funding from the European Union's Horizon 2020 research 560 and innovation programme under the Marie Sklodowska-Curie grant agreement No 561655239 (HAP4MARBLE project, "Multi-functionalization of hydroxyapatite for restoration 562 and preventive conservation of marble artworks"). Prof. Andrea Saccani (DICAM, 563 University of Bologna) is gratefully acknowledged for collaboration in the SEM 564 observation of cross sections.

\section{REFERENCES}

566 [1] Rampazzi L., Rizzo B., Colombo C., Conti C., Realini M., Bartolucci U., Colombini M.P., Spiriti A., Facchin L., The stucco decorations from St. Lorenzo in Laino (Como, Italy): The materials and the techniques employed by the "Magistri Comacini", Anal Chim Acta 630 (2008) 91-100

[2] Blasco-López FJ, Alejandre Sánchez FJ (2013) Porosity and surface hardness as indicators of the state of conservation of Mudéjar plasterwork in the Real Alcázar in Seville. Journal of Cultural Heritage 14:169-173

[3] Natali C., Lorenzini G., Le "ricette" degli stucchi in Italia Settentrionale dal XV al XX secolo. In: Lo stucco: cultura, tecnologia, conoscenza - Atti del convegno di studi Bressanone 10-13 Luglio 2001, Scienza e Beni Culturali XVII 2001. Ed. Arcadia Ricerche [In Italian] 
577 [4] Montana G., Ronca F., The "recipe" of the stucco sculptures of Giacomo Serpotta. J Cult Herit 3 (2002) 133-145

579 [5] Tulliani J.M., Bertolini Cestari C., Study of the degradation causes affecting stucco sculptures from Valentino Castle in Turin, Mater Struct 38 (2005) 425-432

[6] Arcolao C., Dal Bo A., L'influenza delle sostanze proteiche naturali su alcune proprietà degli stucchi. In: Lo stucco: cultura, tecnologia, conoscenza - Atti del convegno di studi Bressanone 10-13 Luglio 2001, Scienza e Beni Culturali XVII 2001. Ed. Arcadia Ricerche [In Italian]

[7] Jroundi F., Gonzalez-Muñoz M.T., Garcia-Bueno A., Rodriguez-Navarro C., Consolidation of archaeological gypsum plaster by bacterial biomineralization of calcium carbonate, Acta Biomater 10 (2014) 3844-3854

[8] Amoroso G.G., Fassina V., Stone decay and conservation, Elsevier, New York, 1983

[9] Van Balen K., Papayanni I., Van Hees R., Binda L., Waldum A., Introduction to requirements for and functions and properties of repair mortars, Materials and Structures 38 (2005) 781-785

[10] Suzuki Y., Matsuya S., Udoh K., Nakagawa M., Tsukiyama Y., Koyano K., Ishikawa K., Fabrication of hydroxyapatite block from gypsum block based on $\left(\mathrm{NH}_{4}\right)_{2} \mathrm{HPO}_{4}$ treatment, Dent Mater J 24(4) (2005) 515-521

[11] Snethlage R., Gruber C., Tucic V., Wendler E., Transforming gypsum into calcium phosphate - the better way to preserve lime paint layers on natural stone? In: Mimoso JM \& Delgado Rodrigues J (Ed), Stone consolidation n Cultural Heritage, (2008) 1-13

[12] Molina E., Rueda-Quero L., Benavente D., Burgos-Cara A., Ruiz-Agudo E., Cultrone G., Gypsum crust as a source of calcium for the consolidation of carbonate stones using a calcium phosphate-based consolidant, Construction and Building Materials 143 (2017) 298-311

[13] Perry R.H., Green DW, Maloney JO (1997) Perry's chemical engineer's book, 7th edn. McGraw-Hill, New York

[14] Sassoni E., Naidu S., Scherer G.W., The use of hydroxyapatite as a new inorganic consolidant for damaged carbonate stones. J Cult Herit 12 (2011) 346-355

[15] Sassoni E., Graziani G., Franzoni E., Repair of sugaring marble by ammonium phosphate: comparison with ethyl silicate and ammonium oxalate and pilot application to historic artifact. Mater Design 88 (2015) 1145-1157

[16] Sassoni E., Graziani G., Scherer G.W., Franzoni E., Preliminary study on the use of ammonium phosphate for the conservation of marble-imitating gypsum-stuccoes, In: 
611 Papayianni I., Stefanidou M., Pachta V. (Eds), Proceedings of the 4th Historic Mortars

612 Conference HMC2016, Santorini (GR), 10-12 October 2016, p. 391-398

613 [17] Lebedev A.L., Kosorukov V.L., Gypsum Solubility in Water at $25^{\circ} \mathrm{C}$, Geochem Int 55 $614 \quad$ (2017) 205-210

615 [18] Dorozhkin S.V., Calcium orthophophates, Biomatter 1 (2011) 121-164

616 [19] Ishikawa K., Suzuki Y., Matsuya S., Nakagawa M., Koyano K., Effects of pH on the 617 transformation of gypsum to carbonate apatite in the presence of ammonium hydrogen phosphate, Key Eng Mat 309-311 (2006) 199-202

[20] Matteini M., Moles A., Giovannoni S., Calcium oxalate as a protective mineral system for wall paintings: methodology and analyses, III Int. Symp. Conservation of Monuments in the Mediterranean Basin, ed. V. Fassina, H. Ott, F. Zezza, 1994, pp. 155-162

[22] Burgos-Cara A., Ruiz-Agudo E., Rodriguez-Navarro C., Effectiveness of oxalic acid

[21] Matteini M., Inorganic treatments for the consolidation and protection of stone artefacts, Conservation Science in Cultural Heritage 8 (2008) 13-27

\section{treatments for the protection of marble surfaces, Materials and Design 115 (2017) 82-92}

[23] Naidu S., Sassoni E., Scherer G.W., New treatment for corrosion-resistant coatings for marble and consolidation of limestone, in Stefanaggi M., Vergès-Belmin V. (Eds), "Jardins de Pierres - Conservation of stone in Parks, Gardens and Cemeteries", Paris (F) 22-24 June 2011, p. 289-294

[24] Naidu S., Scherer G.W., Nucleation, growth and evolution of calcium phosphate films on calcite, Journal of Colloidal and Interface Science 435 (2014) 128-137

[25] Graziani G., Sassoni E., Franzoni E., Scherer G.W., Hydroxyapatite coatings for marble protection: Optimization of calcite covering and acid resistance, Applied Surface Science 368 (2016) 241-257

[26] Naidu S., Blair J., Scherer G.W., Acid-resistant coatings on marble, J Am Ceram Soc 99 (2016) 3421-3428

[27] Sassoni E., Franzoni E., Sugaring marble in the Monumental Cemetery in Bologna (Italy): characterization of naturally and artificially weathered samples and first results of consolidation by hydroxyapatite, Applied Physics A: Materials Science \& Processing 117 (2014) 1893-1906

[28] Sassoni E., Graziani G., Ridolfi G., Bignozzi M.C., Franzoni E., Thermal behavior of Carrara marble after consolidation by ammonium phosphate, ammonium oxalate and ethyl silicate, Materials and Design, 120 (2017) 345-353 
644 [29] Sassoni E., Graziani G., Franzoni E., Scherer G.W., Some recent findings on marble 645 conservation by aqueous solutions of diammonium hydrogen phosphate, MRS Advances, DOI: $10.1557 / a d v .2017 .45$

647 [30] Sandrolini F., Franzoni E., Sassoni E., Diotallevi P.P., The contribution of urban-scale environmental monitoring to materials diagnostics: a study on the Cathedral of Modena (Italy), Journal of Cultural Heritage, 12 (2011) 441-450

[31] Ma X., Balonis M., Pasco H., Toumazou M., Counts D., Kakoulli I., Evaluation of hydroxyapatite effects for the consolidation of a Hellenistic-Roman rock-cut chamber tomb at Athienou-Malloura in Cyprus, Construction and Building Materials 150 (2017) 333-344

[32] GomismV., Saquete M.D., García-Cano J., CaSO4 solubility in water-ethanol mixtures in the presence of sodium chloride at $25^{\circ} \mathrm{C}$. Application to a reverse osmosis process, Fluid Phase Equilibria 360 (2013) 248-252

[33] Eliaz N., Metoki N., Calcium Phosphate Bioceramics: A Review of Their History, Structure, Properties, Coating Technologies and Biomedical Applications, Materials 10 (2017) 334

[34] Lebedev A.L., Kosorukov V. L., Gypsum solubility in water at $25^{\circ} \mathrm{C}$, Geochemistry International, 55 [2] (2017) pp. 205-210

[35] Evans A.G., Drory M.D., M.S. Hu, The cracking and decohesion of thin films, J. Mater. Res., 3 [5] (1988) 1043-1049

[36] Sassoni E., Graziani G., Franzoni E., An innovative phosphate-based consolidant for limestone. Part 1: Effectiveness and compatibility in comparison with ethyl silicate, Construction and Building Materials, 102 (2016) 918-930

[37] Sassoni E., Graziani G., Franzoni E., An innovative phosphate-based consolidant for limestone. Part 2: Durability in comparison with ethyl silicate, Construction and Building Materials, 102 (2016) 931-942

[38] Graziani G., Sassoni E., Scherer G.W., Franzoni E., Penetration depth and redistribution of an aqueous ammonium phosphate solution used for porous limestone consolidation by brushing and immersion, Construction and Building Materials 148 (2017) 571-578

[39] Osticioli I., Botticelli G., Matteini P., Siano S., Pini R., Matteini M., Micro-Raman analysis on the combined use of ammonium oxalate and ammonium phosphate for the consolidation and protection of carbonate stone artifacts, Journal of Raman Spectroscopy 48 (2017) 966-971 